\title{
Implementation of Number Block Game Techniques for Learning Number Symbol in Early Childhood
}

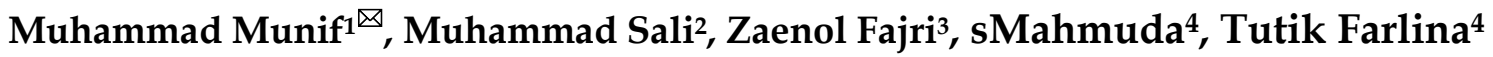 \\ Pendidikan Agama Islam, Universitas Nurul Jadid, Paiton, Probolinggo, Indonesia(1) \\ Pendidikan Agama Islam, UIN Sultan Aji Muhammad Idris Samarinda, Indonesia(2) \\ Pendidikan Guru Madrasah Ibtidaiyah, Universitas Nurul Jadid, Paiton, Probolinggo, \\ Indonesia(3); Pendidikan Islam Anak Usia Dini, Universitas Nurul Jadid, Paiton, Probolinggo, \\ Indonesia( $(4)$ \\ DOI: $10.31004 /$ obsesi.v6i4.2074
}

\begin{abstract}
The low ability to recognize number symbols in children aged four to five years is a problem that has always been a hot conversation between educators, parents, and the general public. Children aged 4 to 5 years should recognize the number symbols one through ten. The purpose of this study is how the number block game technique is used to recognize number symbols in children aged four to five years. This type of research is qualitative-descriptive using a case study approach. The results showed that using the number block game can create a fun learning atmosphere, make it easier for children to absorb learning material, especially in recognizing number symbols, and make children feel happy and at ease. The teacher ensures that the learning objectives are met during the learning activities. The findings of this study indicate that the use of number block game techniques to improve the ability to recognize number symbols in children aged four to five years can be carried out effectively and efficiently.
\end{abstract}

Keywords: number block game; learning number symbols; early childhood

\begin{abstract}
Abstrak
Rendahnya kemampuan mengenal lambang bilangan pada anak usia empat sampai lima tahun merupakan permasalahan yang selalu menjadi perbincangan hangat antara pendidik, orang tua, dan masyarakat umum. Anak usia 4 sampai 5 tahun harus mengenal simbol angka satu sampai sepuluh. Tujuan dari penelitian ini adalah bagaimana teknik permainan balok angka digunakan untuk mengenali simbol angka pada anak usia empat sampai lima tahun. Jenis penelitian ini adalah kualitatif-deskriptif dengan menggunakan pendekatan studi kasus. Hasil penelitian menunjukkan bahwa dengan menggunakan permainan balok angka dapat menciptakan suasana belajar yang menyenangkan, memudahkan anak menyerap materi pembelajaran terutama dalam mengenal lambang bilangan, dan membuat anak merasa senang dan tentram. Selama kegiatan pembelajaran, guru memastikan bahwa tujuan pembelajaran terpenuhi. Temuan penelitian ini menunjukkan bahwa penggunaan teknik permainan balok angka untuk meningkatkan kemampuan mengenal simbol angka pada anak usia empat sampai lima tahun dapat dilakukan secara efektif dan efisien.
\end{abstract}

Kata Kunci: permainan blok angka; belajar simbol angka; anak usia dini

Copyright (c) 2022 Muhammad Munif, et al.

$\square$ Corresponding author:

Email Address : m.munifmpdi@gmail.com (Paiton, Probolinggo, JawaTimur, Indonesia)

Received 15 November 2021, Accepted 15 January 2022, Published 27 February 2022 


\section{INTRODUCTION}

Early childhood is a special moment in a child's life as they are between zero and six when growth and development are at their maximum (Iltiqoiyah, 2020; Wulandari \& Purwanta, 2021; Amaliyah et al., 2022). One of the development in early childhood is cognitive ability. Cognitive development is one component of development that has a significant impact on children's daily lives because practically all activities carried out by children involve thinking skills to acquire new knowledge (Yaswinda et al., 2020; Mariana et al., 2019). According to Filtri \& Sembiring, cognitive development is a process through which people can enhance their ability to apply their information to acquire new knowledge (Yaswinda et al., 2020; Mariana et al., 2019; Zubaidah, 2021). Problem-solving, logical thinking, and symbolic thinking are aspects of cognitive development (Fajri, 2010; Firdausiah, 2021). On the other hand, this scientific paper focuses on features of cognitive development in the realm of symbolic thinking, namely the ability to detect number symbols. The ability to recognize numerical characters is a subset of a child's ability to identify and understand symbols that represent the quantity of an object. According to Susanto, interpreting number symbols, connecting thoughts with number symbols, and pairing and writing number symbols with things up to ten are all part of a child's ability to recognize number symbols when they are four to five years old (Qholisya, 2019). As a result, cognitive capacity is defined as a person's ability to think and manage his mind to learn new knowledge valuable in his future life.

Early childhood children's inability to understand number symbols has always been a hot topic among educators, parents, and the general public (Tohet et al., 2022).. Children aged four to five years are expected to count various items from one to ten, understand the notion of numbers, recognize number symbols, and recognize letter symbols in terms of cognitive development in the field of symbolic thinking (Khadijah \& Amelia, 2020). The inability of children aged four to five years in knowing the symbol of numbers is usually often indicated through some cases such as children who are still flipped in reciting or mentioning the symbol of numbers, children who only know "one, two, three,..." without knowing what the shape of the number symbol is, and the child who already knows some number symbols but still often flipped or wrong in writing it. Even youngsters should recognize number symbols but do not know their shape at all. There are many more cases or difficulties with identifying number symbols in early life (Wulandari \& Purwanta, 2021). Children will find it easier to transmit and interpret information if they are familiar with the symbols for numbers. A fundamental feature of mathematics is the use of numerical characters, because children begin to perceive and explore numerous mathematical parts of their world at a young age, recognizing number symbols is critical for survival in early life. One of the most crucial abilities for youngsters to have and perfect is recognizing number symbols (Gandana et al., 2017; Mubarak \& Humaidah, 2021). Recognizing number symbols become the most crucial abilities because it is a fundamental mathematical skill that will later come in handy in children's daily lives. Furthermore, a child's ability to understand number symbols can influence their readiness to advance to the next level of education. According to a longitudinal study conducted by the World Health Organization, "early mathematics skills substantially predict later mathematics skills" (Yurnalisma, 2018; Mudarris et al., 2022), which suggests that early mathematics skills accurately predict later mathematical abilities.

As a result, numerous studies have attempted to identify ways to assist young children, particularly those aged four to five, recognize number symbols. For example, in Weni's analysis, the use of smart cards media for Pertiwi Banteran to increase the recognition of numerical characters is sufficient. However, it is unfortunate that the smart card medium utilized is merely colored asturo paper, easily destroyed and not lengthy. Gandana et al., (2017) said that employing Cuisenaire blocks as a medium, indicates that in youngsters aged 4-5 years, the capacity to recognize the symbols of numerals 1-10 has improved each cycle dramatically. The observations from pre-action to process I revealed a $1 \%$ rise, with an average percentage of $35 \%$ of able children and $65 \%$ of children who were not competent in pre-action and $36 \%$ of able children and $64 \%$ of children who were not able in cycle I. From the first 
cycle, where $36 \%$ of children were able, and $64 \%$ were not, to cycle II, where $65 \%$ of children were able, and $35 \%$ were not, the average rate was $36 \%$ of able children and $64 \%$ of children who were not. From cycle II, where $65 \%$ of children are capable, and $35 \%$ are not, to cycle III, where $83 \%$ of children are able, and $17 \%$ are not, and have attained success indicators, there is $83 \%$ of able children and $17 \%$ of children who are not. Children gain practical experience and skills in using learning media (Zamroni et al., 2021; Umiarso \& Hidayati, 2022); children can develop the ability to recognize symbols of numbers 1-10 in children, but can also recognize shapes, colors and train children's memory. The disadvantage is that media is challenging to come by in some locations (Baharun, 2016).

According to Badrun Zaman in Multahada, one of the needs for learning media is to be durable, strong, and durable. The media is constructed of auto paper, so, if it is broken, we must recreate it, making the intelligent card media less effective in helping children recognize number symbols (Adhimah, 2019; Multahadan \& Rosiyanah et al., 2020; Munif et al., 2022). Other research findings include "The Effect of Singing Method Assisted by Microsoft PowerPoint Media on the Ability to Recognize Number Symbols in Children" by Dewi, Jampel, and Tegeh. The utilization of Microsoft PowerPoint media is also quite good because it has kept up with the times. Whenever it comes to early childhood education, the utilization of Microsoft PowerPoint media is still less than ideal (Dewi et al., 2017). Furthermore, because early life is still characterized by tangible thinking, it would be beneficial to continue offering concrete or genuine media to children (Mundiri et al., 2022; Wahid et al., 2022).

According to research findings from Gandana, Hasendra, Nursa'idah, Mayasari, and Qholisa, young children aged four to five still lack their comprehension of the symbols for numerals one to ten (Gandana et al., 2017; Hasendra, 2019; Nursa'idah, 2021; Mayasari, K., 2015; Qholisya, 2019). The authors propose using number block media packaged into playing activities or referred to as "Games" to address the low ability to recognize number symbols in children aged four to five years and find more precise and efficient solutions than the results of previous studies. This number block media games is called "Numerical Blocks". Numerical Blocks is used because children aged four to five years are still at the stage of playing and thinking concretely, the author offers the Number Block Game to help them overcome their lack of capacity to recognize number symbols. As a result, imparting number symbols to youngsters aged four to five through play activities involving tangible and lasting media such as number blocks will be much easier and more efficient.

According to Piaget's hypothesis, early childhood is in the preoperational period (Age 2-7 years), which begins at two years and lasts until about seven years. The child thinks in symbols throughout this time but does not yet perform cognitive procedures. This means the child is unable to employ logic and change, combine, or separate concepts or thoughts. The child's growth consists of generating world experiences through adaptation and striving toward (concrete) stages to utilize logical thinking. The kid can mentally represent events and objects (semiotic functions or signals) and engage in symbolic play at this late period. According to developmental theory, a child's intelligence evolves through time. A child's cognitive growth entails the acquisition of knowledge and the development or building of mental abilities. So, according to Hijriyati's Piaget Theory, which argues that knowledge is formed through learning activities or activities (Hijriati, 2016: Sholeha et al., 2022; Hefniy et al., 2022), Piaget's theory of development is one of the reasons the author picked number block game activities for research. Even Montessori has put the number block media to the test to help young children become more familiar with number symbols. As a result, one of the learning media recommended by Montessori to help young children recognize number symbols is the number block media (Musliani, 2018).

According to Hasendra, a beam is a three-dimensional space structure with six sides, twelve edges, and eight corner points formed by three pairs of squares or rectangles, at least one of which is of different sizes (Hasendra, 2019). Fajri, on the other hand, defined number blocks as an educational game tool made up of various shaped pieces of wood or plastic that are played by arranging or connecting them according to their imagination to make or resemble a building (Fajri, 2010). He also stated that the number block media consists of 10 
wooden parts, each specific number. This number block media is square and can promote early childhood cognitive abilities. To encourage early children's cognitive skills, number blocks are visual media usually formed of wood or plastic-type materials with three-dimensional shapes that are generally square or rectangular. Each block unit represents a number symbol. The number block media used in this study is composed of various colored wooden number blocks. This number block has a square shape with a bit of hole in the middle that will be used to insert it into an oblong wooden pole later (Sari \& Abdullah, 2015). Either block unit symbolizes a number symbol, and there is a number symbol or a black number sign on each side. Because children aged four to five years are expected to recognize and count the characters of numbers one to ten, a number block with a number symbol on each side of the number one to ten is required.

Based on the issues stated above, it is crucial to study the implementation of number block technique for learning number symbol in early childhood. This study can be used to know how the Number Block Game can help youngsters aged four to five years enhance their capacity to recognize number symbols. So that, children can learn the number symbol while playing the number blocks.

\section{METHODOLOGY}

This study is classified as a qualitative descriptive study. Qualitative descriptive approaches research by describing and describing the state of things and research subjects based on the facts that appear or as they are (Moleong, 2010; Moleong, 2011; Sugiyono, 2013; Creswell, 2012). This research is a natural accumulation of data to explain the phenomena, with the researcher as the primary instrument, data sources sampled purposefully. Triangulation (mixed) is the data gathering approach, data analysis is inductive or qualitative, and qualitative results stress meaning rather than generalization (Sugiyono, 2014; Anggito, A., \& Setiawan, 2018). The descriptive form requires the researcher or writer to describe the issues and themes discussed in narrative writing (Moleong, 2011a). As a result, the qualitative-descriptive type of data processing can be defined as a method of data processing that involves analyzing and describing phenomena or problems related to the object of research by presenting data in greater depth to the object of research and in narrative form rather than numbers or figures.

The case study research was the method used in this study. The case study research methodology is part of a qualitative method that aims to go further into a specific case by bringing together a variety of data sources (Moleong, 2010; Sugiyono, 2013). A case study, according to Creswell, is an investigation of bounded systems or cases (Creswell, 2012). A point is intriguing to examine because it has unique characteristics that value others, at least for the researcher (Maryam, 2018). According to Patton in Fajriatunnisah, A case study is a study of the uniqueness and complexity of a single case to understand the point in a given context, circumstance, and time (Fajriatunisah dan Syahbuddin, 2021). Researchers should be able to capture the case's complexity using this strategy. He further stated that this research was carried out since the subject is unusual, relevant, and valuable to readers and society. By knowing the case in-depth, the researcher will capture the importance of the community's interests of a specific organization or group.

The advantage of case studies over other types of research is that they allow researchers to go deep into a topic. However, due to the nature of the case study, the information gained is subjective, which means that it is just for the individual in question and may not apply to other people in the same situation. In other words, information generalization has minimal application. Case studies aren't used to test hypotheses; instead, the findings of case studies can lead to theories that can be examined in future research. Many ideas, concepts, and principles, as well as case study findings, can be developed.

Observation, interviews, and documentation were employed as research instruments. The observational data collection approach monitors human behavior, work processes, natural events, and observed responders, specifically about student learning activities utilizing 
number blocks. Interviews were done with classroom teachers who used number block games to teach their students. In comparison, documentation is employed to keep track of current and historical events. The record could be in the form of photographs, essays, or someone's significant works (Herdiansyah, 2013).

This study was carried out at Raudlatul Athfal Al Azhar Paiton Probolinggo during the odd semester (I) of the academic year 2021/2022, focusing on learning activities involving the use of number block games to introduce number symbols to young children. Figure 1 are the procedures for doing research on the Use of Number Block Game Techniques to Recognize Number Symbols in Early Childhood.

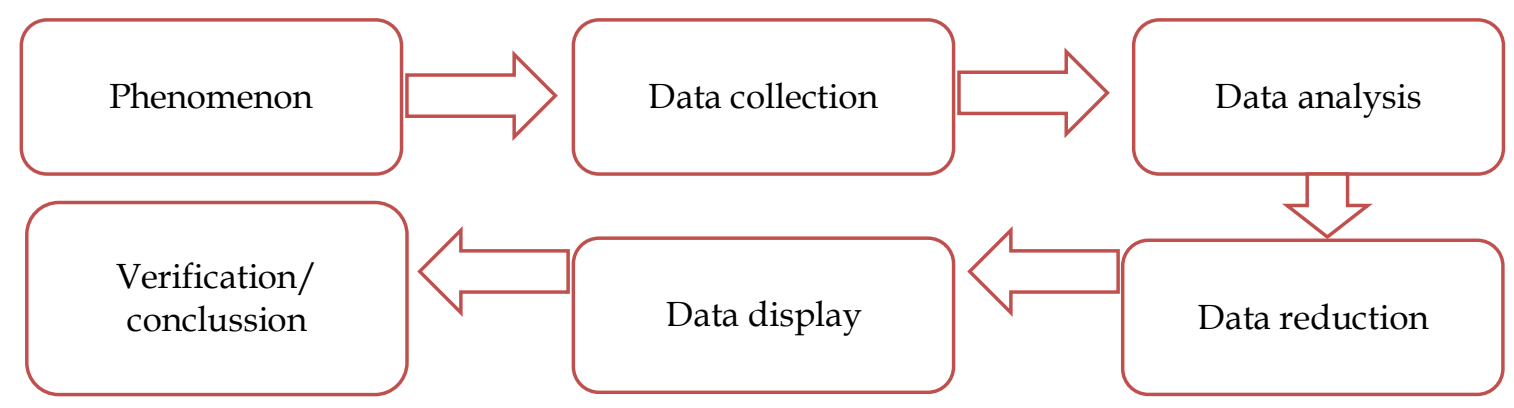

Figure 1. Implementation of the research process (Moleong, 2011)

According to Essa, there are several steps to introducing number symbols to young children using number blocks: First, one-to-one Correspondence. The process by which children learn to grasp numbers by matching items that match other things. The youngster identifies one block by pointing to the number one block, two blocks by pointing to the partnership with two, and so on until the tenth block is named. Second, rote counting (number memory) is the capacity to count (repeat) numbers to assist children in comprehending the significance of a number. Thrid, cunting using logic (rational counting). When a kid correctly associates the name of a number with a succession of calculated items, the child understands the meaning of numbers and their introduction (Nursa'idah, 2016).

The three phases of identifying number symbols using number blocks can be used as a foundation for creating activities for children aged four to five years to recognize number symbols from one to ten. To introduce number symbols to children aged four to five years through the number block game, first lift the number block with the number one symbol, then ask the kid to take one number block while counting it, and so on. In the second stage, students are asked to name the number symbols on the one to ten number blocks. The youngster is then requested to categorize the number blocks according to the number symbols provided on the number blocks in the third stage. The fourth phase entails allowing youngsters to compete in a game involving number blocks arranged in sequence from one to 10 and inserted onto a wooden pole. The objective of the number block game in this study is to introduce the number symbols one to ten and arrange the number blocks in a sequential order beginning with one.

\section{RESULTS AND DISCUSSION}

This study's sample was conducted in RA Al Azhar Paiton Probolinggo. The following is how the instrument was used in this study: interview observation and documentation

\section{The findings of the number block game observation of learning activities}

The learning process took place on Monday, August 9, 2021. The teacher created a lesson plan that includes the number block game media utilized before beginning the class. The teacher walked into class with a cheery and charming demeanor. Before starting the teacher, the teacher greets the students and has a question-and-answer session with them regarding the content that has been covered. Students sing "One-One I Love Mother" with the 
teacher accompanying them, pointing fingers 1,2 , and 3 . The teacher communicates the learning objectives by displaying the number block media used in class. The teacher demonstrates how to play number blocks.

The following procedures are followed to apply number block game activities to introduce number symbols to early childhood: 1) The teacher presents the notion of number symbols by demonstrating one object and its number symbol, two number symbols, etc. 2) The teacher creates a tool for a number block game. 3) The teacher invites the children to name the number symbols on the number blocks ranging from one to ten, 4) The instructor welcomes the children to count the number of number blocks on each side with a symbol ranging from one to ten, 5) The Teacher explains the rules for playing number blocks and what the student will receive as a prize if they succeed, and 6) The teacher asks the children to compete in playing number blocks in sequence from one to ten. Figure 2 shown one of the process when the teacher presented the number and its symbol to the children.

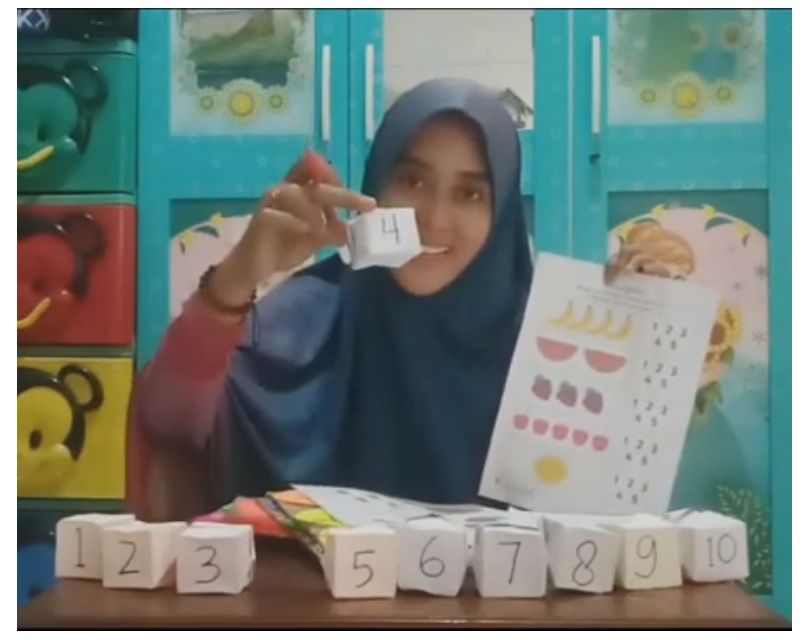

Figure 2 Teachers are showing the number of object and its symbol

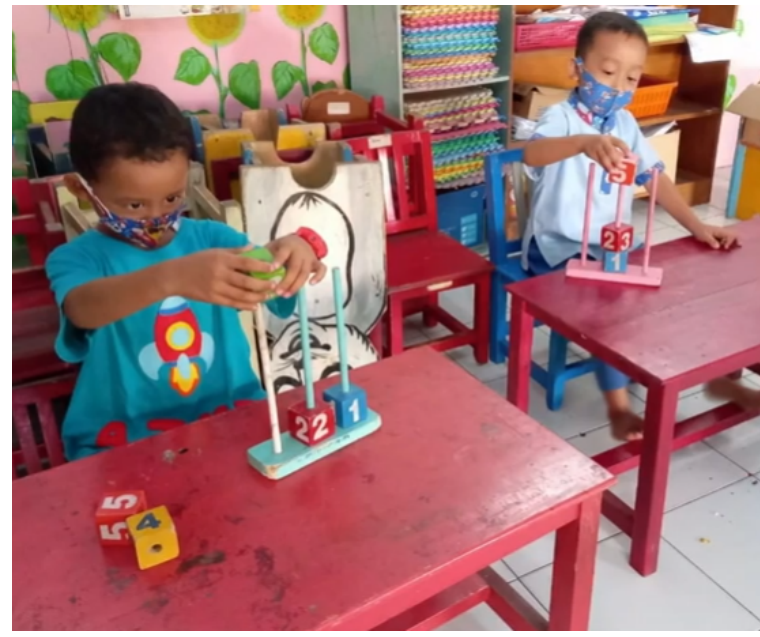

Figure 1 Students can count and arrange the number blocks

In general, learning activities to recognize number symbols through number block games are designed or presented as games. Due to competitions, children will be more joyful and enjoy undertaking exercises to recognize number symbols. Furthermore, children between the ages of four and five are still in the playing stage. When a child is joyful while undertaking activities to recognize number symbols, what the child learns that day will survive a long time in the child's mind or become long-term memory.

\section{The interview findings of learning exercises, including the number block game}

An interview was performed with Farah Artika as the classroom instructor at RA Al Azhar regarding students' grasp of recognizing number symbols and student activities and learning outcomes before learning about implementing the number block game to recognize number symbols. Following the learning deployment utilizing the number block game, interviews were performed. According to Farah, before using the number block game, children were less excited about learning, resulting in poor student learning outcomes. However, after playing the number block game, students become happier and more engaged in their studies, leading to a greater understanding of the material that challenged their study's number symbols.

\section{The outcomes of the documenting of number block game learning activities}

Obtaining data regarding student learning outcomes that are not sufficient, one of which is about numbers, based on the documentation findings. Numbers continue to be a challenge for students. And after utilizing the number block game to learn, it was discovered 
that the results of student work, such as a portfolio of sorting numbers from 1 to 10, were correct and that learning outcomes has improved.

This number block activity is one of the most effective and appropriate ways to introduce number symbols to children aged four to five. Number block media is an excellent way to help children aged four to five recognize the signs for numbers one to ten. Given that children between the ages of four and five are in the concrete thinking stage. It will be easier to educate children on using tangible media such as number blocks in this environment. Natural forms and meanings can be found in concrete media previously described in abstract form.

Furthermore, the number block media presented in the shape of this game can provide children with hands-on familiarity with the symbols of numbers one to ten. So that youngsters may see the form of the number symbols one through ten and the concept of the number sign. Furthermore, number blocks are learning media that are very suitable for teaching media requirements, such as being safe, durable, and multipurpose, using materials that are easy to find, easy to use by children, and flexible, or being able to be used individually or in groups, following their goals and functions.

Number block games serve a variety of purposes for children, including serving as a fun educational game tool, aiding in the development of children's creativity, and assisting in the development of aspects of cognitive development, particularly in the field of symbolic thinking, such as the ability to recognize number symbols quickly, as well as other parts of child development (Nursiatun, 2015). According to the viewpoint that the number block game can help youngsters build a grasp of number symbols in a fun way so that they can enjoy their activities without feeling compelled (Hasanah, L., \& Nurhasanah, 2020).

This initial stage aims to establish the concept of a number symbol. Children learn that the number one symbol represents the number of items equal to one fruit, the number two sign means the number of objects similar to two pieces, and so on. So that child is expected to understand the shape of the number symbol and the notion of the number symbol itself. In the second stage, the teacher asks the students to name the number symbols on the one to ten number blocks. This phase is designed to aid children in memorizing and remembering number symbols or numbers represented by number blocks. The teacher uses number blocks with the sign one to illustrate and convey the shape of the number one symbol and then moves on to other number symbols.

The teacher should avoid telling parables about the shape of the number symbol because it can lead to children having incorrect notions about the condition of the number symbol (Amalina, 2020). Number one, for example, is like a stick, number two, a duck, number three, an upside-down bird, number four, an overturned chair, etc. Because not all objects used as parables have to be formed like numbers, not all chairs are fashioned like the number four, though; some are round, square, etc. As a result, it would be preferable if the teacher demonstrated or described the shape of the number symbol in its original form rather than a made-up one. The teacher can also use randomization in this second step to see whether the student has memorized the symbols for numbers one to ten. The final phase entails asking the student to sort the number blocks into groups based on the number symbols listed on each side. It is hoped that the child has completed the second step and understands and recalls the shape of the number symbol from one to ten in this third phase. So, in this third stage, the kid's capacity to recognize number symbols from one to ten is further expanded and enhanced by asking the child to count the number of blocks in each form of the number symbol and allowing the child to categorize the number blocks.

More precisely, the kid counts the number of blocks on either side with the symbol one, and so on, until the number blocks represent the number 10. The fourth and last step is to invite the youngsters to compete, inputting the materials from one to ten by inserting them into an elliptical wooden pole.

After taking the first, second, and third stages, this step tries to see how children aged four to five years gain the ability to recognize the symbols of numbers one to ten. When 
performing this final phase, the teacher should explain the game's rules and the child's prize if they succeed.

Rewarding children for engaging in competitions to arrange number blocks from one to ten is an excellent way to pique their interest. Of course, children aged four to five years are anticipated to place number blocks from one to ten in sequence at this age. Through the number block game, children aged four to five years have improved their capacity to recognize the symbols of numbers one to ten by displaying a confident attitude as a form. The number block game offers benefits that make it one of the best treatments for youngsters aged four to five years learning to recognize number symbols. Children can learn to recognize the concept of numbers and number symbols using concrete objects, children will feel happy during activities to recognize number symbols, children will learn to count, children will become acquainted with three-dimensional shapes (blocks), children will learn about classifying or grouping based on the form of number symbols on number blocks, and kids will be able to relate many objects to numbers. As figure 2 shows, after implementing the number blocks game, children can count, arrange, and also remember the symbols of number.

The disadvantage of the number block game is that it can jeopardize children's safety and security if adults do not accompany them because it is played with a number block medium often constructed of wood. The act of tossing a number block by a child without adult supervision is dangerous to the child and those around him. As a result, children must be accompanied by adults, including teachers and parents, when playing the number block game. According to the author's findings from the collection and analysis of literature review sources, whether number block media is packaged in the form of a game or not, both have an impact on the success of early childhood, particularly children aged four to five years in their ability to recognize numbers one to ten.

Based on the findings of a study by Nursa'idah titled "Developing Ability to Recognize Numbers 1-10 Using Number Block Media in Group A TK Kusuma Mulia Al Falah Kediri Regency," which showed a 59.3 percent increase in the activity of recognizing the number symbols one to ten after being given treatment (services) using number blocks (Nursa'idah, 2016). Mayasari also demonstrated it in her research, which revealed a significant increase when the youngsters in Group A were treated with number block games (Mayasari, K., 2015). The capacity of children aged four to five years to recognize the symbols of numbers one to ten is indicated by abilities such as the ability to point to characters of numbers one to ten, copy the signs of numbers one to ten, and connect or match number symbols with things one through ten.

If the children meets these criteria, they can be assumed to recognize the symbols for numerals one through ten. Internal and environmental factors influence the success of number block games in teaching children aged four to five years to recognize number symbols (Sumardi, S., Rahman, T., \& Gustini, 2017). This is because intelligence is crucial in the learning process, the child's intelligence is the internal factor. Their intelligence level influences the ability of children to grasp information during learning activities (Adhimiy, 2019; Br \& Asiya, 2021). If the youngster has good gripping power, number symbols will be easier to understand.

On the other hand, if the infant has low gripping power, it will be challenging to introduce number symbols to the child. This is in line with Masliani's belief that a person's intellect level determines their ability to do great things, follow what is being taught, and their chances of success. Meanwhile, educators' skill level and inventiveness can influence the success of number symbol recognition in children aged four to five years through number block games (Sumardi, S., Rahman, T., \& Gustini, 2017).

Suppose a teacher can innovate in the production of learning media. In that case, he can use current media to create a pleasant learning environment for students, making it more straightforward for them to absorb learning content and feel joyful and comfortable while conducting learning activities. The learning activities and learning goals will be met. According to the authors' findings, introducing the number symbols one to ten to youngsters aged four to five years can be done using a number block game to make it easier for them to understand the number symbols they are learning can be done using a number block game. 


\section{CONCLUSION}

According to the research aims and discussion of research findings, the number block game approach used in the process of identifying number symbols in children aged four to five years can create a fun learning environment, make it easier for children to absorb learning material, especially when it comes to recognizing number symbols, and make children feel happy and at ease during learning activities, ensuring that learning objectives are met. However, the results of this study cannot be generalized in every institution because there are many factors that affect the success of a learning.

\section{ACKNOWLEDGMENT}

The researcher would like to thank the Rector of the University of Nurul Jadid, Paiton, Probolinggo, East Java who has provided motivation and guidance to the researchers, so that this research was completed properly. The researcher also thanked the editor of Obsession for publishing this article.

\section{REFERENCES}

Adhimah, S. (2019). Adversity Quotient: Complementary Intelligence in Establishing Mental Endurance Santri in Pesantren. Jurnal Ilmiah Islam Futura, 19(1), 128-143. https://doi.org/10.22373/jiif.v19i1.3502

Adhimiy, S. (2019). Learning Innovation in Pesantren: The Strategy of Stifin Method for Enhancing Children's Intelligence Potential. TARBIYA: Journal of Education in Muslim Society, 6(2), 233-250. https:// doi.org/10.15408/tjems.v6i2.9247

Amalina, A. (2020). Pembelajaran Matematika Anak Usia Dini di Masa Pandemi COVID-19 Tahun 2020. Jurnal Obsesi: Jurnal Pendidikan Anak Usia Dini, 5(1), 538. https://doi.org/10.31004/obsesi.v5i1.592

Amaliyah, A., Rahman, F., \& Maryam, S. (2022). Enhancement School Competitiveness Through A Literacy Culture Based on Local Wisdom. Jurnal Obsesi: Jurnal Pendidikan Anak Usia Dini, 6(3), 2325-2333. https://doi.org/10.31004/obsesi.v6i3.2094

Anggito, A., \& Setiawan, J. (2018). Metodologi Penelitian Kualitatif. E. D. Lestari, Ed.

Baharun, H. (2016). Pengembangan Media Pembelajaran PAI Berbasis Lingkungan Melalui Model ASSURE. Cendekia: Journal of Education and Society, 14(2), 231-246. https://doi.org/10.21154/cendekia.v14i2.610

Br, R., \& Asiya, D. (2021). Inclusive Education Management in the Development of Cognitive Intelligence of Children. Al-Ishlah: Jurnal Pendidikan, 13(2), 1057-1067. https://doi.org/10.35445/alishlah.v13i2.538

Creswell, J. (2012). Research Design Pendekatan Kualitatif, Kuantitatif dan Mixed. Pustaka Pelajar.

Dewi, N. L. P. A., Jampel, I. N., \& Tegeh, I. M. (2017). Microsoft Power Point Terhadap Kemampuan Mengenal Lambang Bilangan Pada Anak. E-Journal Pendidikan Anak Usia Dini Universitas Pendidikan Ganesha, 5(1), 33-44.

Fajri, Z. (2010). Pembelajaran Kooperatif dengan Menerapkan Teori Brunner Pokok Bahasan Keliling dan Luas Bangun Datar Kelas IVA SD Negeri Tamanan 2 Tahun Ajaran 2009/2010. Universitas Jember.

Fajriatunisah, Syahbuddin, R. (2021). Analisis Home Visit Method dalam Pembelajaran IPS Siswa Kelas V SDN Inpres Tenga di Masa Covid-19. Jurnal Pendidikan IPS, 11(1), 1-9. https://doi.org/10.37630/jpi.v11i1.443

Firdausiah, F. (2021). Implementation of Role-Playing Games in Overcoming Introverted Children. AL-ISHLAH: Jurnal Pendidikan, 13(2), 1394-1402. https:/ / doi.org/10.35445/alishlah.v13i2.629

Gandana, G., Pranata, O. H., \& Yulia Danti, T. Y. (2017). Peningkatan Kemampuan Mengenal Lambang Bilangan 1-10 melalui Media Balok Cuisenaire pada Anak Usia 4-5 Tahun di 
TK At-Toyyibah. Jurnal Paud Agapedia, 1(1), 92-105. https://doi.org/10.17509/jpa.v1i1.7160

Hasanah, L., \& Nurhasanah, A. (2020). Kemampuan Membaca Permulaan Melalui Penggunaan Media Papan Flanel Anak Usia Dini 4-5 Tahun. Jurnal PAUD AGAPEDIA, 2(1), 12-22. https:// doi.org/10.17509/ipa.v2i1.24384

Hasendra, A. (2019). Penggunaan Balok Angka Sebagai Media Pembelajaran Untuk Meningkatkan Kemampuan Kognitif Anak Di Taman Kanak-Kanak Pertiwi Kota Jambi. Jurnal Literasiologi, 2(2), 64-80. https://doi.org/10.47783/literasiologi.v2i2.42

Hefniy, Dinihari, A. N., Aini, N., \& Tunnaja, A. (2022). Management of Parenting Activities in Forming Character of Early Childhood. Jurnal Obsesi : Jurnal Pendidikan Anak Usia Dini, 6(4), 3169-3179. https:/ / doi.org/10.31004/obsesi.v6i4.2065

Herdiansyah, H. (2013). Wawancara Observasi dan Fokus Groups Sebagai Instrumen Penggalian Data Kualitatif. Rajawali Press.

Hijriati. (2016). Tahapan perkembangan kognitif pada masa early childhood. Jurnal Pendidikan Anak, 1(2), 1-17.

Iltiqoiyah, L. (2020). Manajemen Pembelajaran melalui Pendekatan BCCT dalam Meningkatkan Multiple intelligences Anak. Jurnal Obsesi : Jurnal Pendidikan Anak Usia Dini, 5(2), 1368-1381. https:// doi.org/10.31004/obsesi.v5i2.781

Khadijah, \& Amelia, N. (2020). Asesmen Perkembangan Kognitif Anak Usia 5-6 Tahun. Al Athfaal: Jurnal Ilmiah Pendidikan Anak Usia Dini, 3(1), 69-82. https:// doi.org/10.24042/ajipaud.v3i1.6508

Mariana, N., Azis, A., \& Setiawan, I. (2019). Pengembangan Kecerdasan Spritual Anak Usia Dini Melalui Homeschooling. Tarbiyah Al Aulad, 4(1), 27-44.

Maryam, S. (2018). Building Character Education Using Three Matra of Hasan Al-Banna'S Perspective in Pesantren. Jurnal Pendidikan Islam, 4(2), 51-62. https://doi.org/10.15575/jpi.v4i2.2422

Mayasari, K., A. E. R. (2015). Pengaruh Penggunaan Balok-Balok Angka Terhadap Kemampuan Mengenal Lambang Bilangan Pada Anak Kelompok A Di TK Aisyiyah Bustanul Athfal 7 Padangbandung Dukun Gresik. PAUD Teratai, 5(1), 1-7.

Moleong, L. J. (2011b). Metodologi Penelitian Kualitatif. Remaja Rosdakarya.

Moleong. (2011a). Metodologi Penelitian Kualitatif Edisi Revisi. PT REMAJA ROSDAKARYA.

Mudarris, B., Rozi, F., \& Islamiyah, N. (2022). Penggunaan Media Vlog dalam Pengembangan Kemampuan Motorik Anak. Jurnal Ilmiah Potensia, 7(1), 1-10.

Mundiri, A., Baharun, H., \& Hamimah, S. (2022). Early Childhood Behavior Management Strategy based on Fun Learning Environment. Jurnal Obsesi: Jurnal Pendidikan Anak Usia Dini, 6(4), 2583-2595. https:// doi.org/10.31004/obsesi.v6i4.2063

Munif, M., Rozi, F., \& Kulsum, U. (2022). Desain Video Vlog dalam Menumbuhkembangkan Karakter Anak Usia Dini. Manazhim : Manajemen Dan Ilmu Pendidikan, 4(1), 78-93. https://doi.org/10.36088/manazhim.v4i1.1619

Musliani, S. (2018). Peningkatan Intelegensi Dan Hasil Belajar Siswa Melalui Pembelajaran Fungsi Logaritma Menggunakan Model Quantum Learning. MaPan: Jurnal $\begin{array}{llll}\text { Matematika Dan 70-81. } & \text { 6(1), }\end{array}$ https:// doi.org/10.24252/mapan.2018v6n1a7

Nursa'idah. (2016). Menggunakan Media Balok Angka di Kelompok A TK Kusuma Mulia AlFalah Kabupaten Kediri. Universitas Nusantara PGRI Kediri, 1-11.

Nursiatun. (2015). Mengembangkan Kemampuan Kognitif Dalam Mengurutkan Angka 1-10 Menggunakan Metode Bermain Menyusun Balok-Balok Angka Pada Anak Kelompok A TK Baitussalam Tulungagung. Universitas Nusantara PGRI Kediri, 1(8), 1-12.

Qholisya, N. (2019). Pengaruh Permainan Balok Angka Terhadap Kemampuan Berhitung pada Anak TK B Bustaannur.

Rosiyanah, R., Yufiarti, Y., \& Meilani, S. M. (2020). Pengembangan Media Stimulasi Sensori Anak Usia 4-6 Tahun Berbasis Aktivitas Bermain Tujuh Indera. Jurnal Obsesi : Jurnal Pendidikan Anak Usia Dini, 5(1), 941-956. https://doi.org/10.31004/obsesi.v5i1.758 
Rozi, F., Mubarak, A. F., \& Humaidah. (2021). Penggunaan Media Permainan Bola Angka Terhadap Kemampuan Mengenalkan Konsep Bilangan 1-10 pada Anak. 10(2), 266-277.

Sholeha, W., \& Anggraini, Y. (2022). Intercultural Communication : Strategy to Improve School Competitiveness Based on Public Demand. Jurnal Obsesi: Jurnal Pendidikan Anak Usia Dini, 6(4), 438-447. https:/ / doi.org/10.31004/obsesi.v6i4.2123

Sugiyono. (2013). Metode Penelitian Pendidikan Pendekatan Kuantitatif. ALFABETA.

Sugiyono. (2014). Metode Penelitian Pendidikan Pendekatan Kuantitatif, Kualitatif dan R\&D. Alfabeta.

Sumardi, S., Rahman, T., \& Gustini, I. S. (2017). Peningkatan Kemampuan Anak Usia Dini Mengenal Lambang Bilangan Melalui Media Playdough. Jurnal PAUD Agapedia, 1(2), 190-202. https:// doi.org/10.17509/jpa.v1i2.9359

Tohet, M., Aini, Q., \& Imamah, N. N. (2022). Anger Management In Improving Teacher Performance In School. Al-Tanzim : Jurnal Manajemen Pendidikan Islam, 6(1), 243-253.

Umiarso, \& Hidayati, N. (2022). Improving Children â€TM s Cognitive Intelligence Through Literacy Management. Jurnal Obsesi: Jurnal Pendidikan Anak Usia Dini, 6(3), 15881598. https:// doi.org/10.31004/obsesi.v6i3.1817

Wahid, A. H., Qodriyah, K., \& Wahyuni, S. (2022). Building a Literacy Culture Based on Local Wisdom through Women â€TM s Leadership. Jurnal Obsesi: Jurnal Pendidikan Anak Usia Dini, 6(4), 2533-2543. https://doi.org/10.31004/obsesi.v6i4.2044

Wulandari, H., \& Purwanta, E. (2021). Pencapaian Perkembangan Anak Usia Dini di Taman Kanak-kanak selama Pembelajaran Daring di Masa Pandemi Covid-19. Jurnal Obsesi: Jurnal Pendidikan Anak Usia Dini, 5(1), 452-462. https://doi.org/10.31004/obsesi.v5i1.626

Yaswinda, Y., Yulsyofriend, Y., \& Sari, H. M. (2020). Analisis Pengembangan Kognitif dan Emosional Anak Kelompok Bermain Berbasis Kawasan Pesisir Pantai. Jurnal Obsesi : Jurnal Pendidikan Anak Usia Dini, 5(2), 996-1008. https://doi.org/10.31004/obsesi.v5i2.711

Yurnalisma, \& F. (2018). Meningkatkan Kemampuan Mengenal Lambang Bilangan Satu Sampai Lima Melalui Media Balok Angka bagi Anak Tunagrahita Sedang Kelas VII di SLBN1 Padang. Jurnal Penelitian Pendidikan Kebutuhan Khusus, 6, 156-164.

Zamroni, Amir, \& Saleha, L. (2021). Pengelolaan APE Berbahan Limbah untuk Meningkatkan Kecerdasan Kognitif Anak. Jurnal Obsesi: Jurnal Pendidikan Anak Usia Dini, 5(2), 1382-1395. https://doi.org/10.31004/obsesi.v5i2.763

Zubaidah. (2021). Penerapan Media Gambar Berseri dalam Meningkatkan Bahasa Ekspresif Anak Usia Dini. Murobbi; Jurnal Ilmu Pendidikan, 5(2), 257-272. 